\title{
Intravenous prenalterol in acute and chronic heart failure.
}

P.C. Kirlin ${ }^{1}$, B. Pitt ${ }^{2}$ and B.R. Lucchesi ${ }^{3}$

1. Research Fellow, Michigan Heart Association, Lathrup Village, Michigan, USA.

2. Cardiology Division, Department of Internal Medicine, University of Michigan Medical Center, Ann Arbor, M1chigan 48109, USA

3. Department of Pharmacology and Upjohn Center for Clinical Pharmacology, University of Michigan, Ann Arbor, Michigan 48109, USA

ABSTRACT

The new inotropic agent prenalterol was administered intravenously in a canine model of acute ischemic heart fallure and in patients with severe chronic heart failure. Experimental heart failure in anesthet1zed dogs was induced by two vessel coronary artery constriction and intravenous prenalterol $(0.005-15 \mu \mathrm{g} / \mathrm{kg} / \mathrm{min})$ was compared to dobutamine $(0.001-30 \mu \mathrm{g} / \mathrm{kg} / \mathrm{min})$ and saline. Significant dose-dependent increases in left ventricular $\mathrm{dP} / \mathrm{dt}$ max $_{\text {, }}$ cardiac output and non-1schemic zone contractile force and significant reductions in systemic vascular resistance were present during infusions of both inotropic agents. H1gh dose dobutamine caused greater increases in mean arterlal pressure and pressure rate product with a trend toward greater increases in heart rate. However, nelther inotropic agent significantly improved ischemic zone contractlle force. Prenalterol possessed a markedly longer hemodynamic half-11fe than dobutamine (3.0 hours compared to 1.7 minutes ). 
Nine patients with severe chronlc heart fallure (left ventricular ejection fraction mean $\pm S D 17 \pm 5 \%$, cardiac index $1.7 \pm 0.41 / \mathrm{m} 1 \mathrm{n} / \mathrm{m}^{2}$ ) responded to intravenous prenalterol (1, 4, and $8 \mathrm{mg})$ with significant increases in cardlac index, left ventricular ejection fraction and left ventricular stroke work index. Left ventricular fllling pressure, mean right atrial pressure and pulmonary arterlolar resistance were significantly reduced. No significant differences were present among peak responses to the three doses employed. An inverse correlation between basal heart rate and increase in left ventricular ejection fraction following prenalterol was noted.

The mechanisms by which prenalterol causes hemodynamic improvement appear to include a direct inotropic effect, a reduction in left ventricular outflow resistance and a reduction in left and right ventricular filling pressure (venodilating effect). The net result is an upward and leftward shift of the depressed ventricular function curve.

Both prenalterol and dobutamine were associated with sustained ventricular tachyarrhythmias in the experimental acute low output state and two digitalized patients with ischemic cardiomyopathy developed transient ventricular tachycardia after prenalterol administration. These findings indicated that adrenergic stimulants should be administered in severe ischemic states with careful monitoring.

\section{INTRODUCTION}

New advances in the pharmacological therapy of low cardiac output states have included the introduction of vasodilator agents and the introduction of catecholamine inotropic agents dopamine and dobutamine. These inotropic agents, however, are restricted to parenteral administration and cardiac glycosides remain the only avallable oral inotroplc agents for long-term therapy of heart failure. Prenalterol is a new orally and parenterally effective catecholamine-like inotropic agent with a chemical structure (Flgure 1) simlar to 1soproterenol. Prenalterol has been shown to 
cause relatively selective increases in myocardial contractility in normal experimental animals [1] and human volunteers [2,3] with lesser effects on heart rate and blood pressure. Limited Information, however, is avallable regarding 1ts effects in low cardlac output states. In order to assess the efflcacy of acute intravenous prenalterol administration in experimental and clinical heart fallure and to compare 1ts effects in the acute ischemic low output state with those of dobutamine, the following studies were undertaken in a canine model of acute heart fallure and in patients with chronic severe heart fallure.

\section{METHODS}

\section{Experimental acute 1schemic heart fallure}

Nineteen male mongrels weighing (meantSEM) $18.9 \pm 0.7 \mathrm{~kg}$ (range 11.6 to $25 \mathrm{~kg}$ ) were anesthetized with $0.5-0.8 \mathrm{ml} / \mathrm{kg}$ intravenous Dial-Urethane and mechanically ventilated on room alr via endotracheal tube by Harvard respirator with a tidal volume of $15-25 \mathrm{ml} / \mathrm{kg}$ and a rate of $10-20$ cycles/min. Respiratory settings were adjusted to maintain arterial $\mathrm{pH}, \mathrm{PO}_{2}$ and $\mathrm{PCO}_{2}$ within normal limits. Arterial pressure was monitored by carotid artery cannulation and a continuous infusion of $30 \mathrm{ml} / \mathrm{h}$, physiological saline was administered via the external jugular vein. Following left fifth intercostal space thoracotomy and formation of a pericardial cradle, the heart was instrumented as shown in Figure 2: Brodie-Walton open arch strain gauges were sutured into the myocardium of the right ventricular (RV) free wall in an area remote from subsequent coronary artery constriction and in the anterior left ventricular (LV) free wall in the distribution of the left anterior descending (LAD) coronary artery, which was subsequently rendered ischemic. Measurements of non-ischemic zone contractile force were obtained from the RV strain gauge and measurements of Ischemic zone contractile force from the LV strain gauge. Triplicate thermodilution cardiac outputs were determined by Columbus Cardiac Output Computer using $2.0 \mathrm{ml}$ room temperature saline injections in the right atrium with a pulmonary artery thermister. Left ventricular end-diastolic pressure (LVEDP) and rate of $\mathrm{LV}$ pressure change ( $\mathrm{LV} \mathrm{dP} / \mathrm{dt}$ ) were obtained from a M1ller 


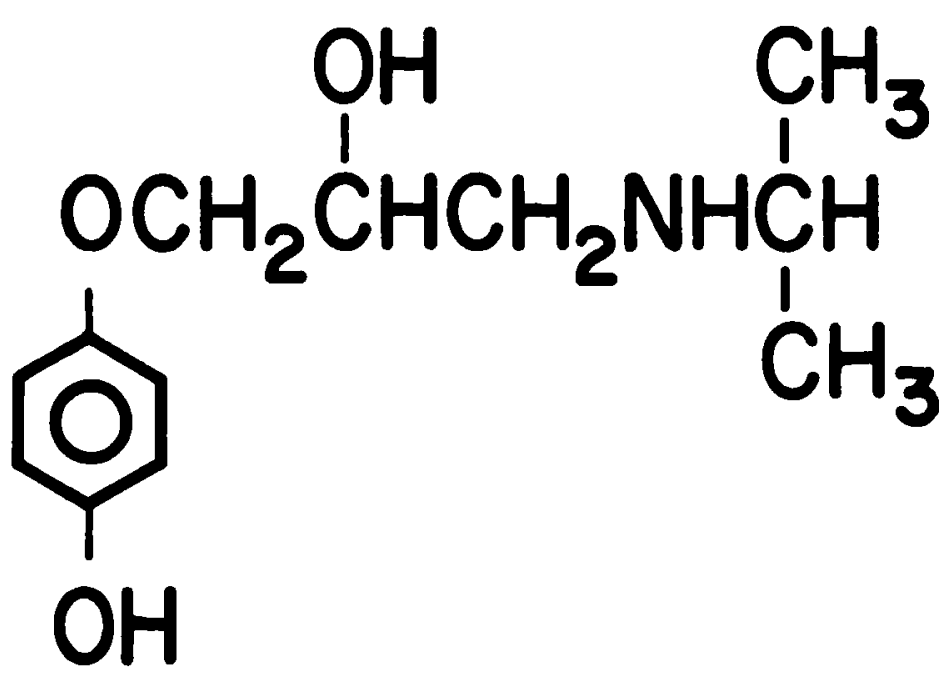

Figure 1. Chemical structure of prenalterol.

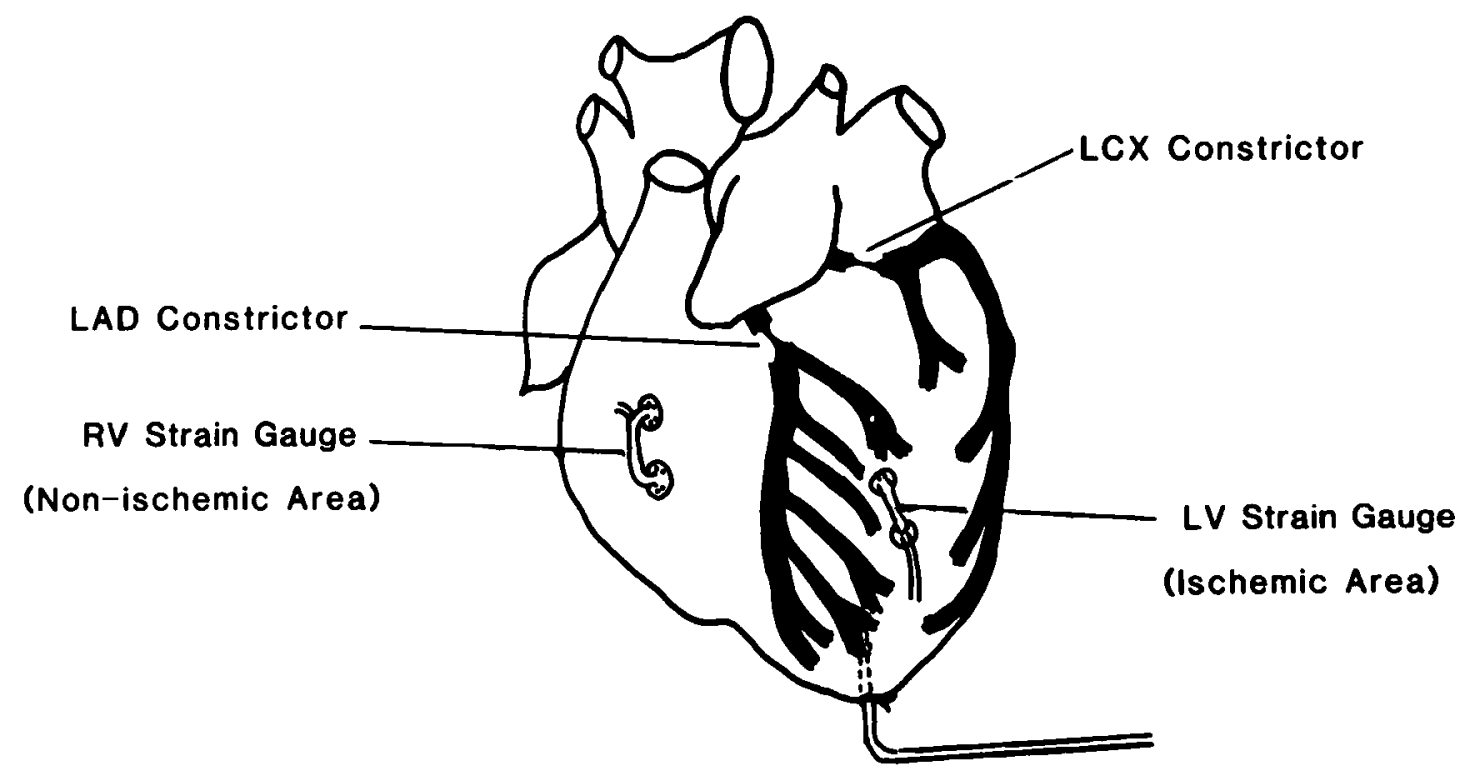

Millar Catheter

Figure 2. Schematic diagram of instrumentation for experimental ischemic low output state. Right atrial catheter and pulmonary artery thermistor for cardiac output determination are not 11 lustrated. 
Mikro-tip catheter in the LV apex. Lead II ECG was monitored throughout each experiment. Screw-type constrictors were placed around the left circumflex (ICX) and LAD coronary arteries for subsequent constriction. A Gross model 7 polygraph was used to record measurements.

An acute ischemic low output state was induced by progressive constriction of the LAD and LCX coronary arteries with the mechanical constrictors until cardiac output and maximum LV dP/dt ( LV dP/dt max $_{\text {f }}$ ) diminished and LVEDP increased. Following baseline measurements in the ischemic low output state, intravenous prenalterol (dose range $0.005-15 \mu \mathrm{g} / \mathrm{kg} / \mathrm{mln}, \mathrm{n}=7$ ) or intravenous dobutamine (dose range $0.01-30 \mu \mathrm{g} / \mathrm{kg} / \mathrm{min}, \mathrm{n}=6$ ) or comparable volumes of saline $(n=6)$ were infused for $10-30 \mathrm{~m} 1 \mathrm{n}$ without re-equilibration between doses.

Dose effect curves (Figures 3-10) are shown for the three groups. Values are expressed as mean \pm SEM. Statistical analysis for dose-response curve comparisons was performed by profile analysis for parallelism and analysis of changes within or between groups by palred or unpalred t-test. Analysis was performed by a computerized statistical program (MIDAS, University of Michigan Statistical Research Laboratory). A p-value of $<0.05$ was considered significant.

Arrhythmia analysis was performed by manual count of ectopic beats for the last five minutes of each infusion. Five animals successfully defibrillated after coronary artery constriction prior to drug administration are included.

\section{Chronic heart fallure in patients}

Nine patients with chronic, severe low output heart failure were studied. Age ranged from 48-70 years with mean \pm SD $59 \pm 7$ years. Five patients were male and four were female. The cause of heart fallure was ischemic in six patients, idiopathic in two patients and alcohollc in one patient. Each patient had symptoms of heart fallure for at least three months prior to study; all patients except one were in New York Heart Association Functional Class III 


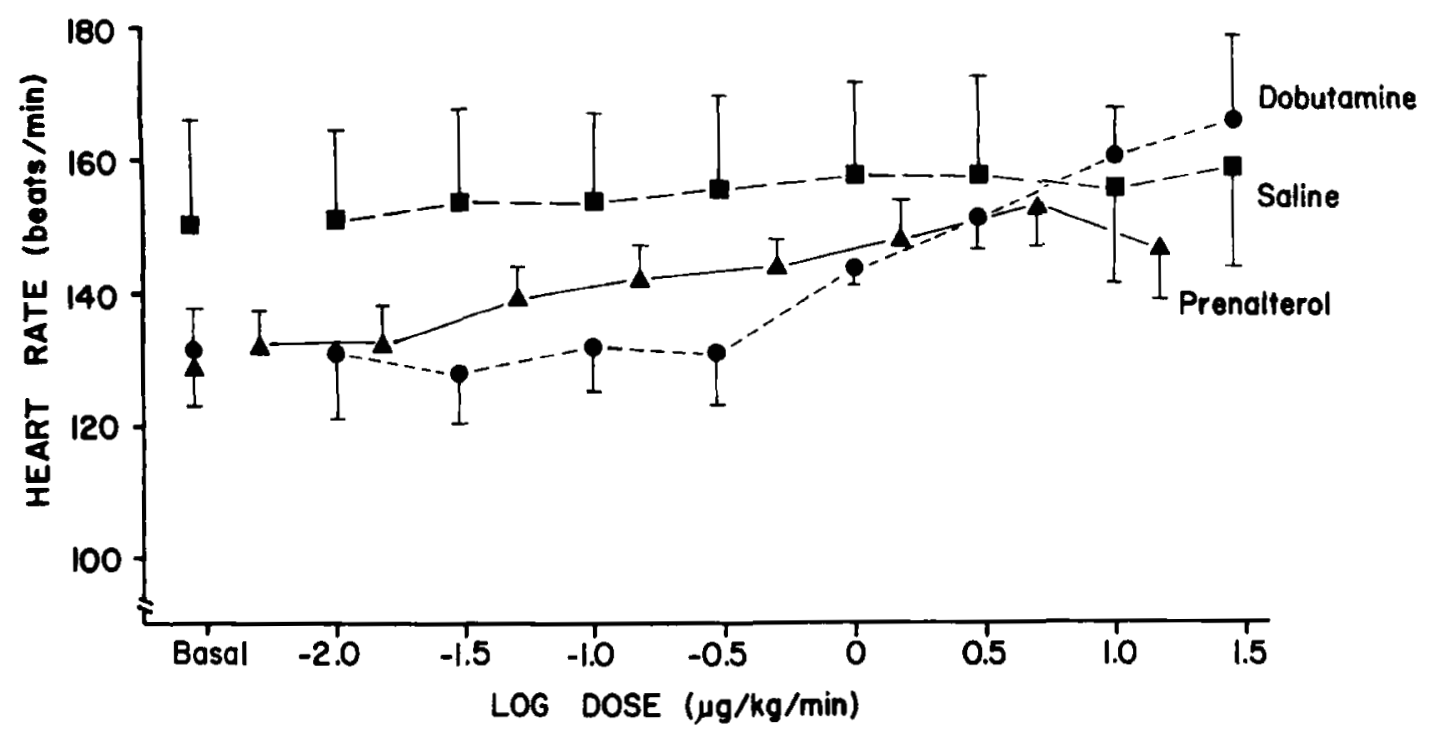

Figure 3. Effect of prenalterol and dobutamine on heart rate. Ne1ther inotropic agent significantly increased heart rate compared to saline controls. Dobutamine tended to cause greater increases than prenalterol $(p<0.10)$. (Reprinted with permission from J Cardiovasc Pharmacol 3:896-905, 1981.)

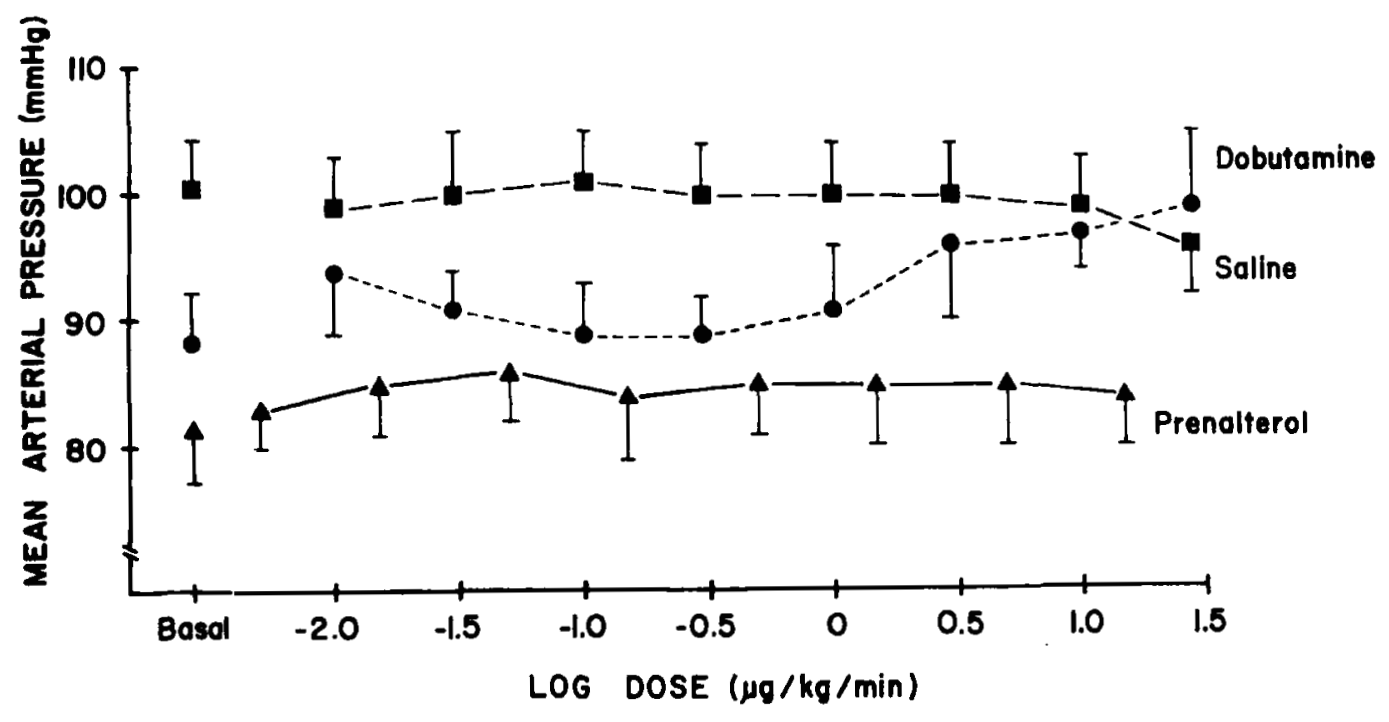

Figure 4. Effect of prenalterol and dobutamine on mean arterial pressure. Dobutamine caused significant elevations compared to sallne controls $(p<0.02)$; prenalterol caused no change. (Reprinted with permission from J Cardiovasc Pharmacol 3:896-905, 1981.) 


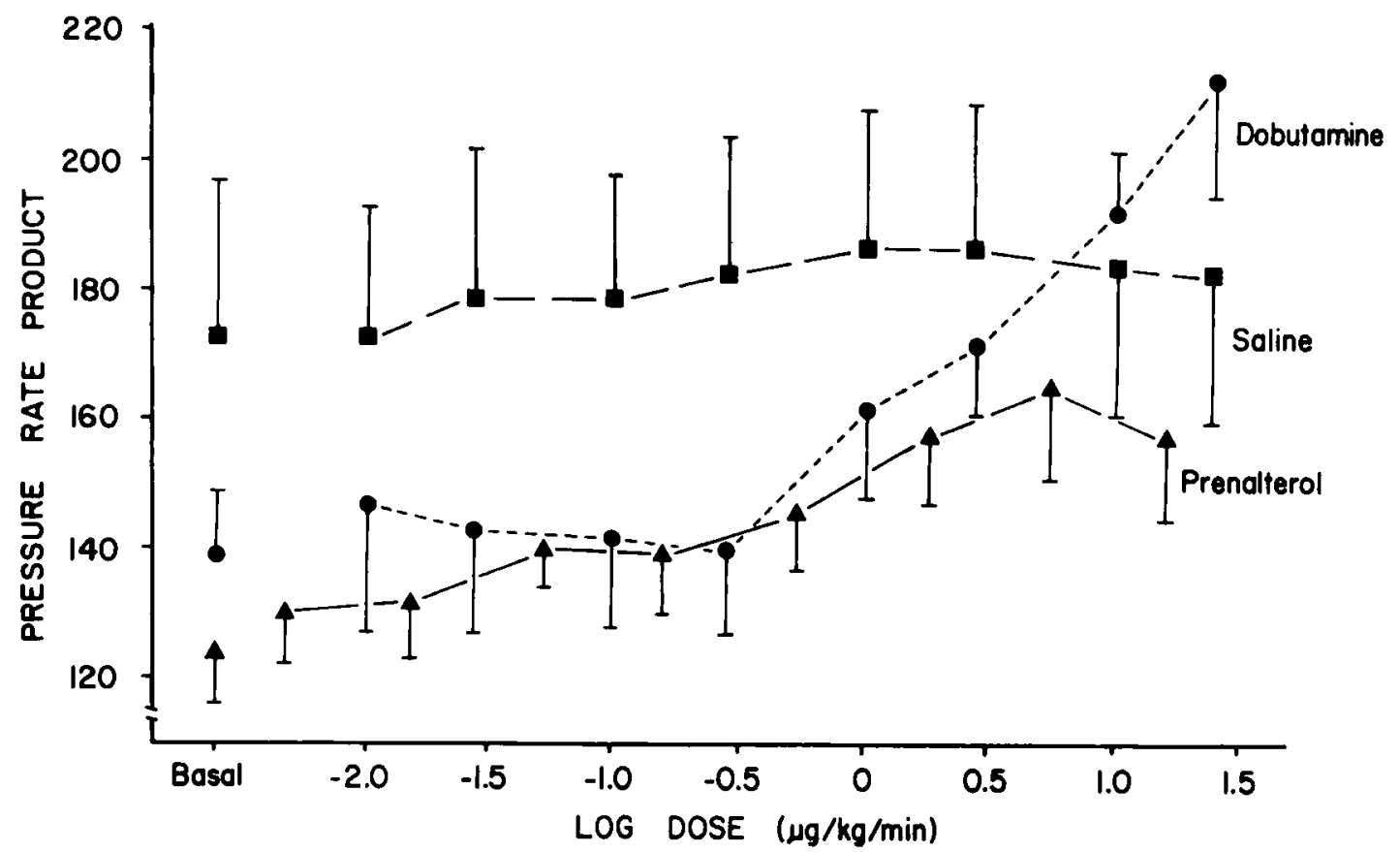

Figure 5. Fffects of prenalterol and dobutamine on pressure rate product. Dobutamine caused significant elevations compared to saline controls $(p<0.03)$ and prenalterol $(p<0.03)$. No significant changes resulted from prenalterol compared to sailne.

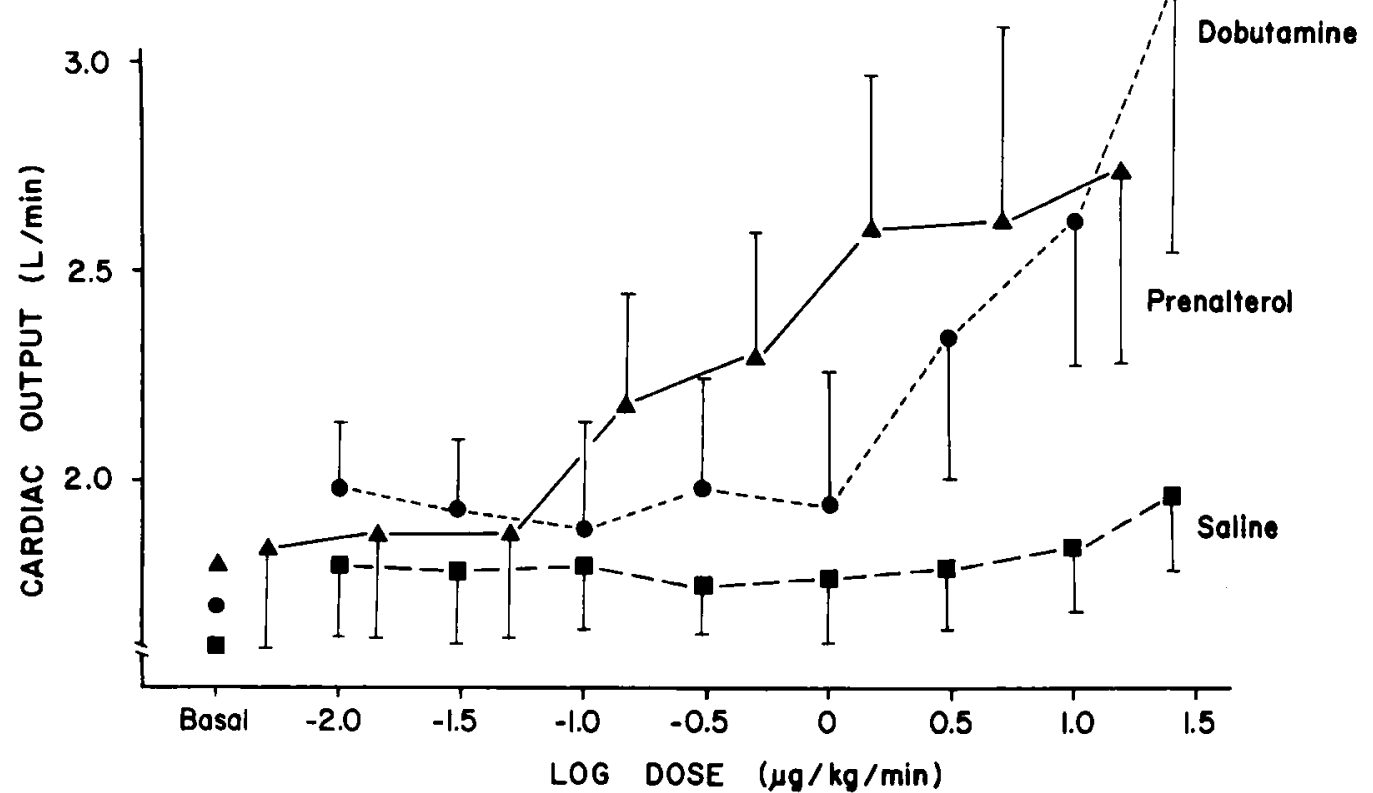

Figure 6. Fffect of prenalterol and dobutamine on cardiac output Compared to saline controls, cardiac output was significantly greater with both prenalterol $(p<0.02)$ and dobutamine $(p<0.01)$. At maximal dose, dobutamine caused a greater increase in cardiac output than prenalterol. (Reprinted with permission from $\mathrm{J}$ Cardiovasc Pharmacol 3:896-905, 1981.) 


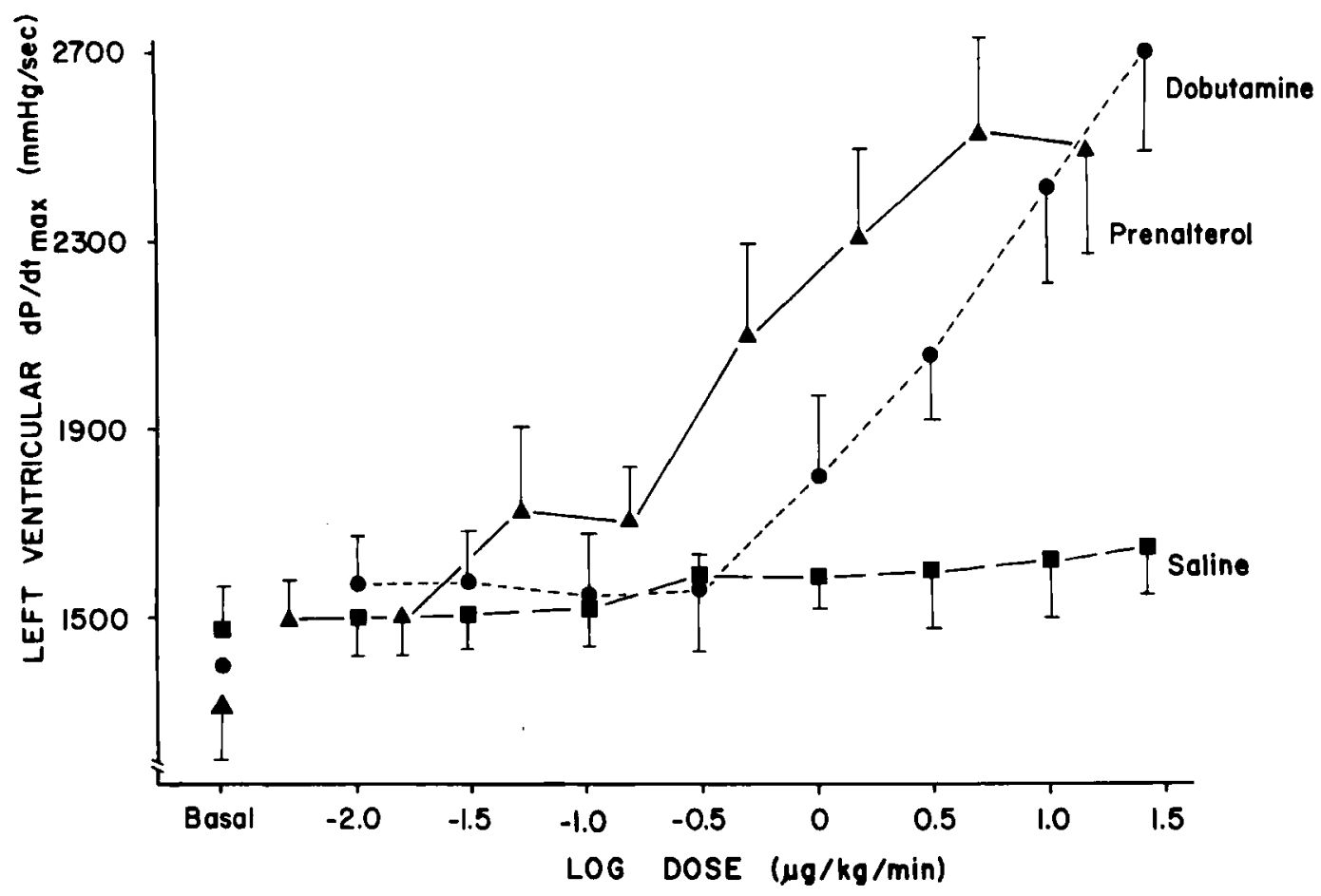

Figure 7. Effect of prenalterol and dobutamine on left ventricular

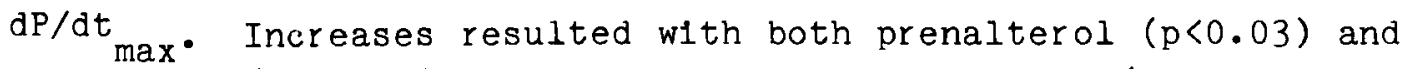
dobutamine $(p<0.001)$ compared to sallne controls. (Reprinted with permission from $J$ Cardiovasc Pharmacol 3:896-905, 1981.)

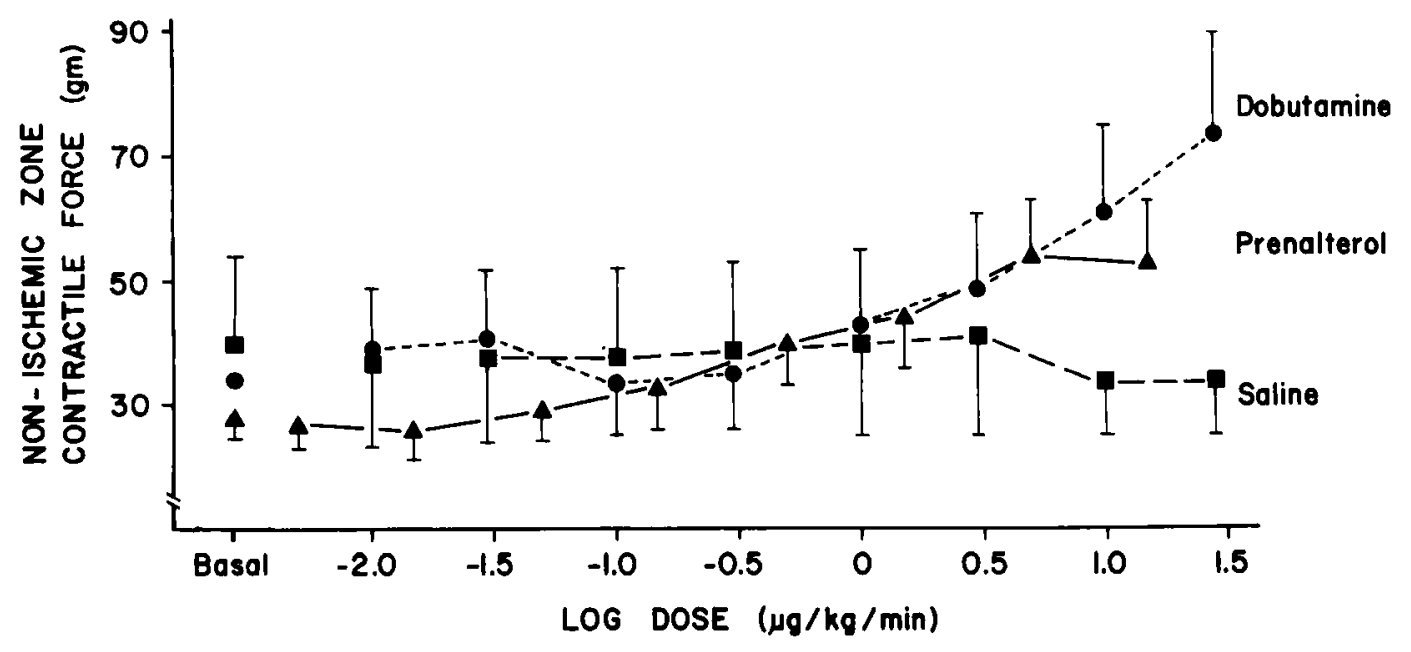

Figure 8. Effect of prenalterol and dobutamine on non-1schemic zone contractile force. Increases resulted with both prenalterol $(p<0.03)$ and dobutamine $(p<0.005)$ compared to saline controls. (Reprinted with permission from J Cardiovasc Pharmacol 3:896-905, 1981.) 


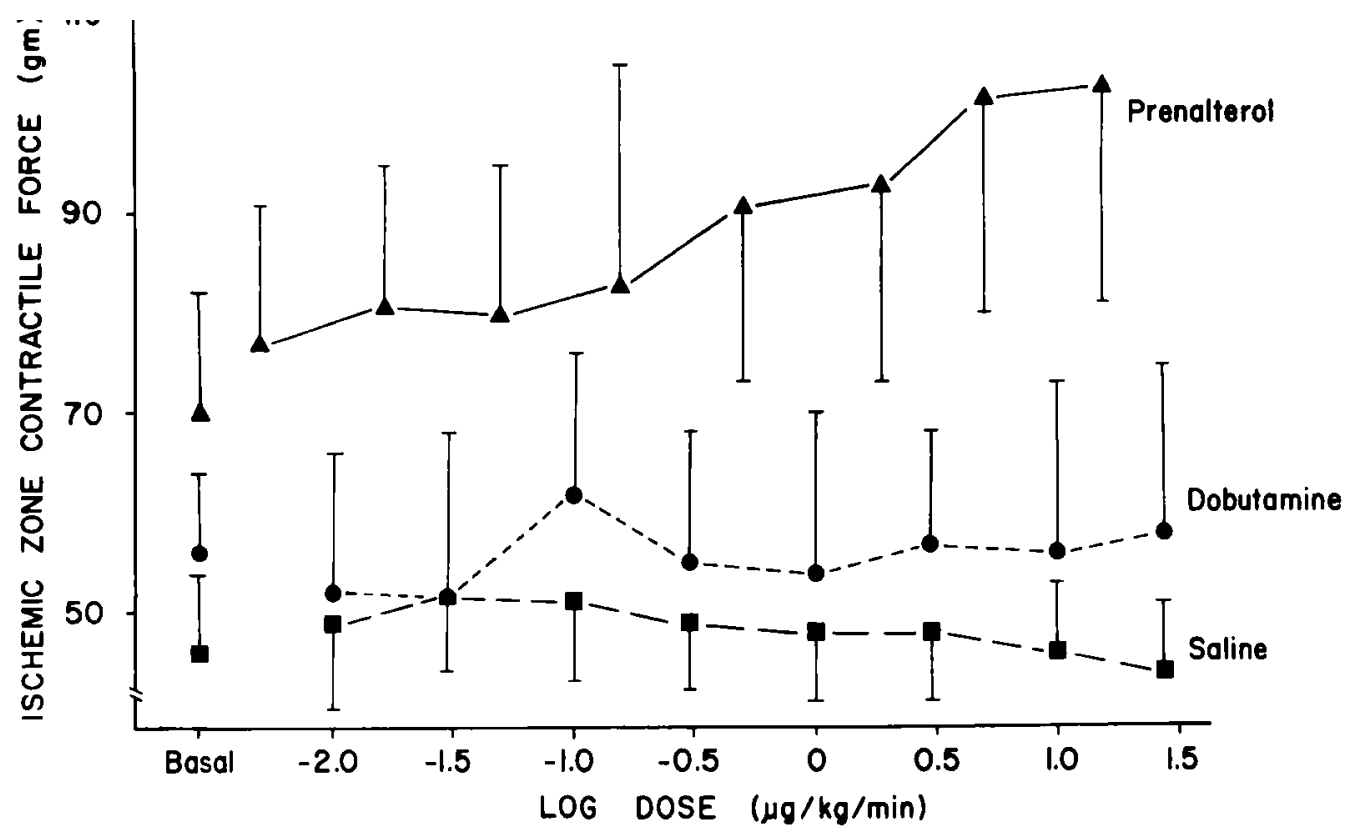

Figure 9. Effect of prenalterol and dobutamine on 1schemic zone contractile force. No significant changes resulted after prenalterol $(p>0.25)$ or dobutamine $(p>0.4)$ compared to saline controls. (Reprinted with permission from J Cardiovasc Pharmacol 3:896-905, 1981.)

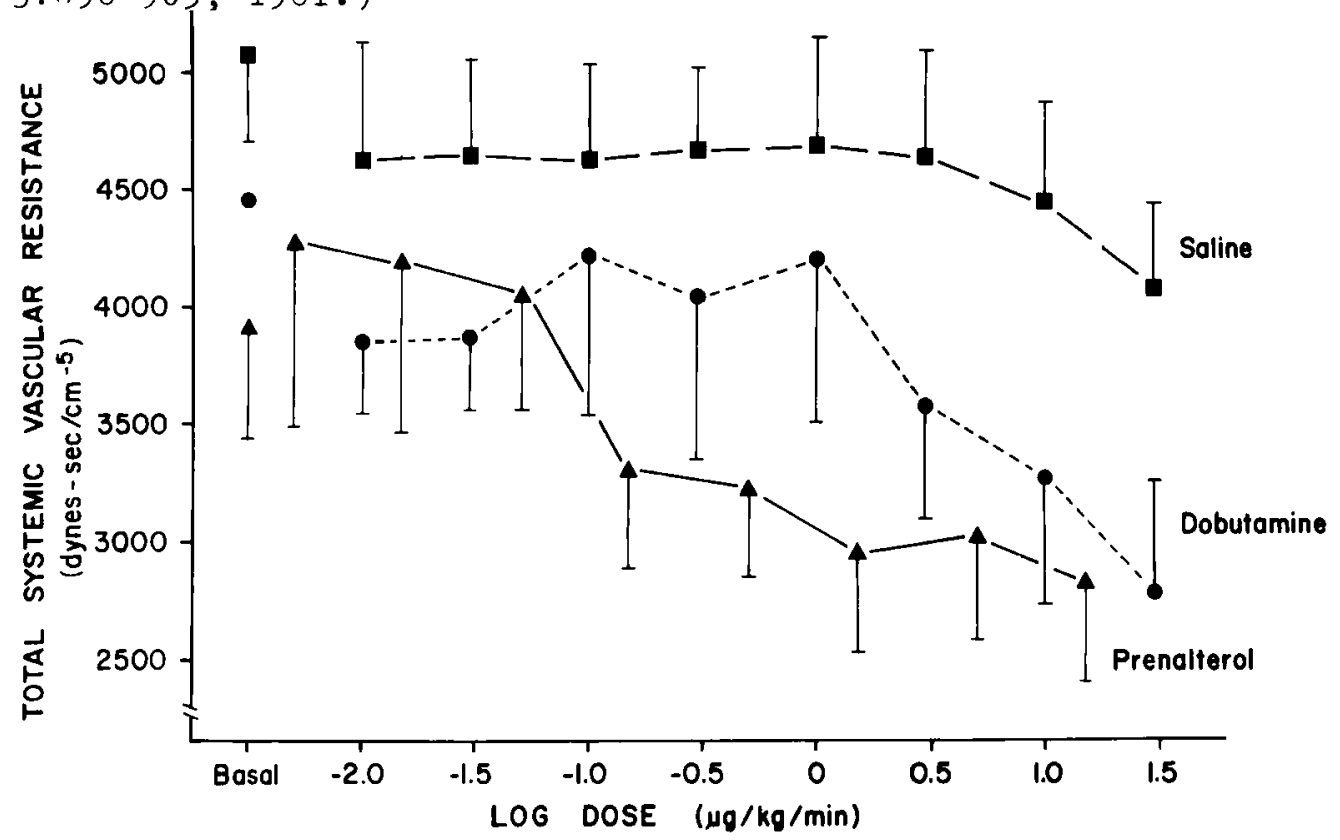

Figure 10. Effects of prenalterol and dobutamine on total systemic vascular resistance. A significant reduction occurred after prenalterol $(p<0.03)$ compared to saline controls. Dobutamine caused a significant reduction in mean total systemic vascular resistance $(p<0.001)$ compared to saline controls without changing profile parallelism significantly $(p>0.15)$. (Reprinted with permission from J Cardiovase Pharmacol 3:896-905, 1981.) 
or IV, and the remaining patient was in Functional Class II. All patients had recelved chronic diuretic therapy and seven had recelved vasodilator therapy for persistent heart fallure symptoms despite digitalis and diuretics. Five of the nine patients were chronically digitalized with oral digoxin in doses of 0.125 or 0.25 mg daily, with serum digoxin levels obtained within six days of study ranging from 0.26 to $1.05 \mathrm{ng} / \mathrm{ml}$ (mean $0.74 \mathrm{ng} / \mathrm{ml}$ ). Patients were studied in the post-absorptive state at least 24 hours after discontinuation of all vasodilator therapy and at least four hours after administration of all other cardiovascular medications. Two patients recelved antiarrhythmic therapy (disopyramide $100 \mathrm{mg}$ orally four times daily and quinidine sulfate $200 \mathrm{mg}$ orally four times daily) at the time of the investigation.

Hemodynamic data were obtained from a triple lumen thermodilution flow directed pulmonary artery catheter inserted through an antecubital vein and from a peripheral arterial catheter ( 7 patients) or blood pressure cuff (2 patients). In addition, left ventricular ejection fraction (LVEF) was obtained by radionuclide ventriculography employing $10-20 \mathrm{mCl}$ of technetium $99 \mathrm{~m}$ for $1 \mathrm{n}$ vivo red cell labeliling. Equilibrlum gated cardiac blood pool 1maging was performed in the modified left anterior oblique position with a gamma camera. All studies were obtalned in the supine position. Directly measured hemodynamic parameters included systemic arterial pressure, right atrial pressure, pulmonary artery pressure, pulmonary artery wedge pressure used as an estimate of left ventricular filling pressure (LVFP), cardiac output (thermodilution technique in 8 patients, indocyanine green dye curves in 1 patient), and radionuclide LVEF. Standard hemodynamic formulae were used for derived parameters. An Electronics for Medicine VRl2 recorder was used to record measurements.

Intravenous prenalterol was administered in doses of 1,4 , and $8 \mathrm{mg}$ at 30 min intervals by infusion pump into a peripheral vein and hemodynamic measurements were obtained at $10 \mathrm{~min}$ and $25 \mathrm{~min}$ after 1 and $4 \mathrm{mg}$ and 10,25 , and $55 \mathrm{~min}$ after $8 \mathrm{mg}$. Peak hemodynamic effects are presented in Figures 11-18. 


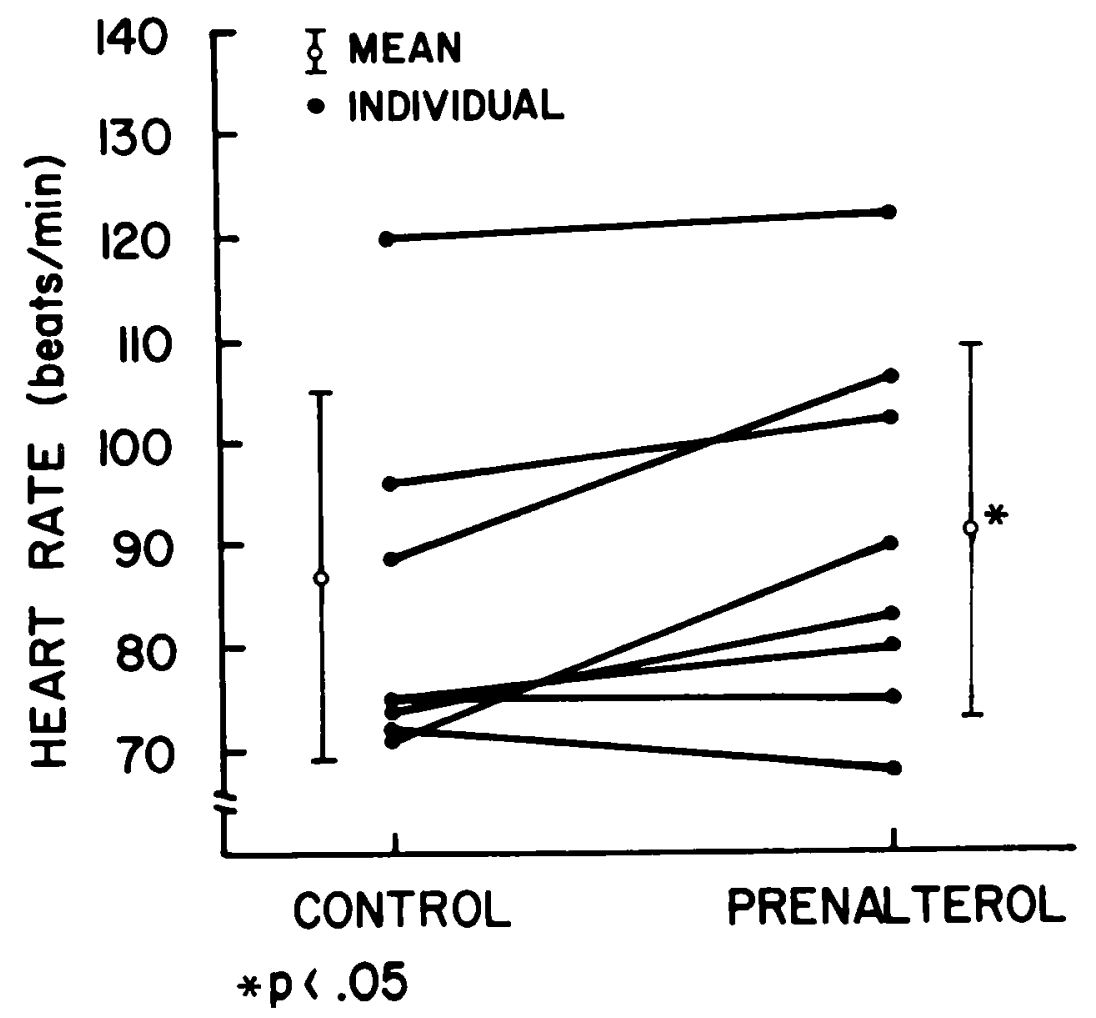

Figure 11. Effect of prenalterol on heart rate in patients. A slight but significant change $(p<0.05)$ occurred.

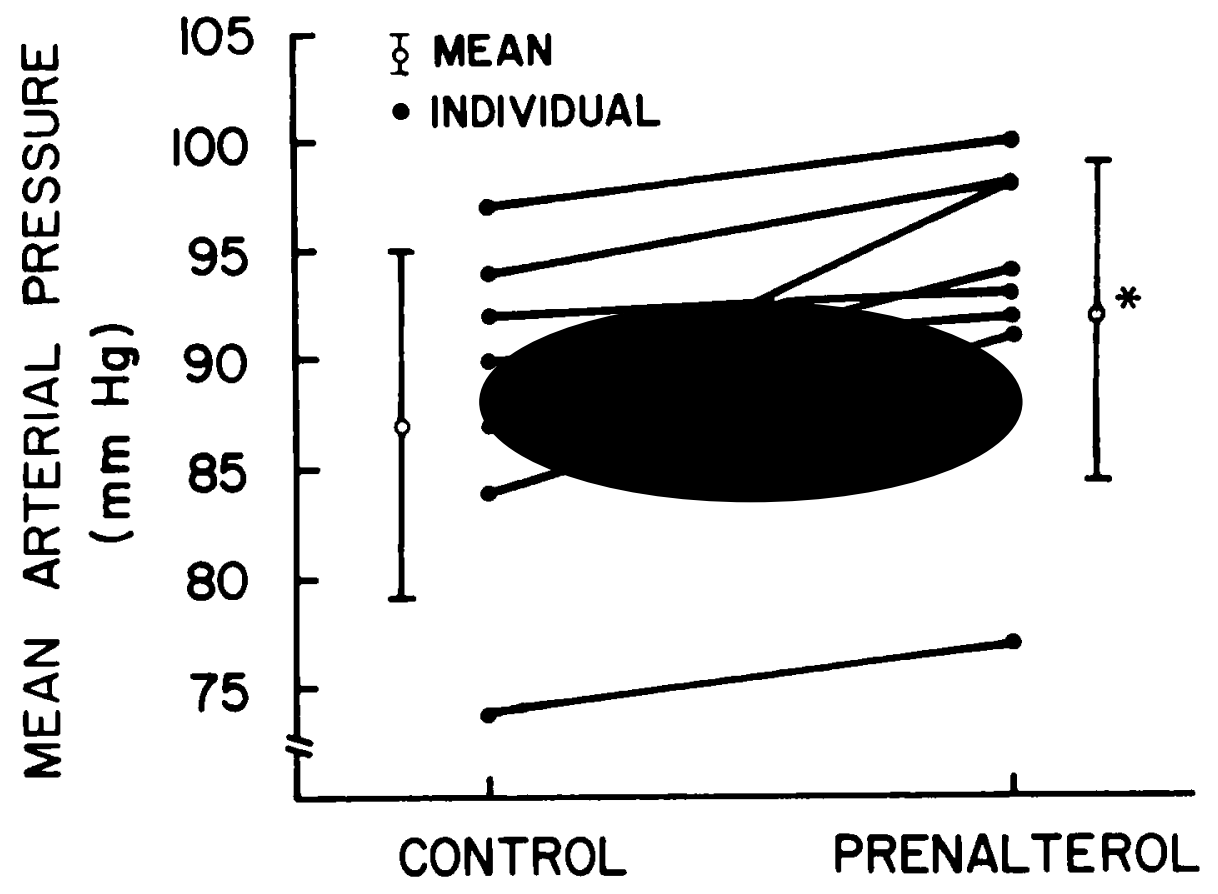
$* p<.01$

Figure 12. Effect of prenalterol on mean arterial pressure in patients. Significant elevation occurred $(p<0.01)$. 


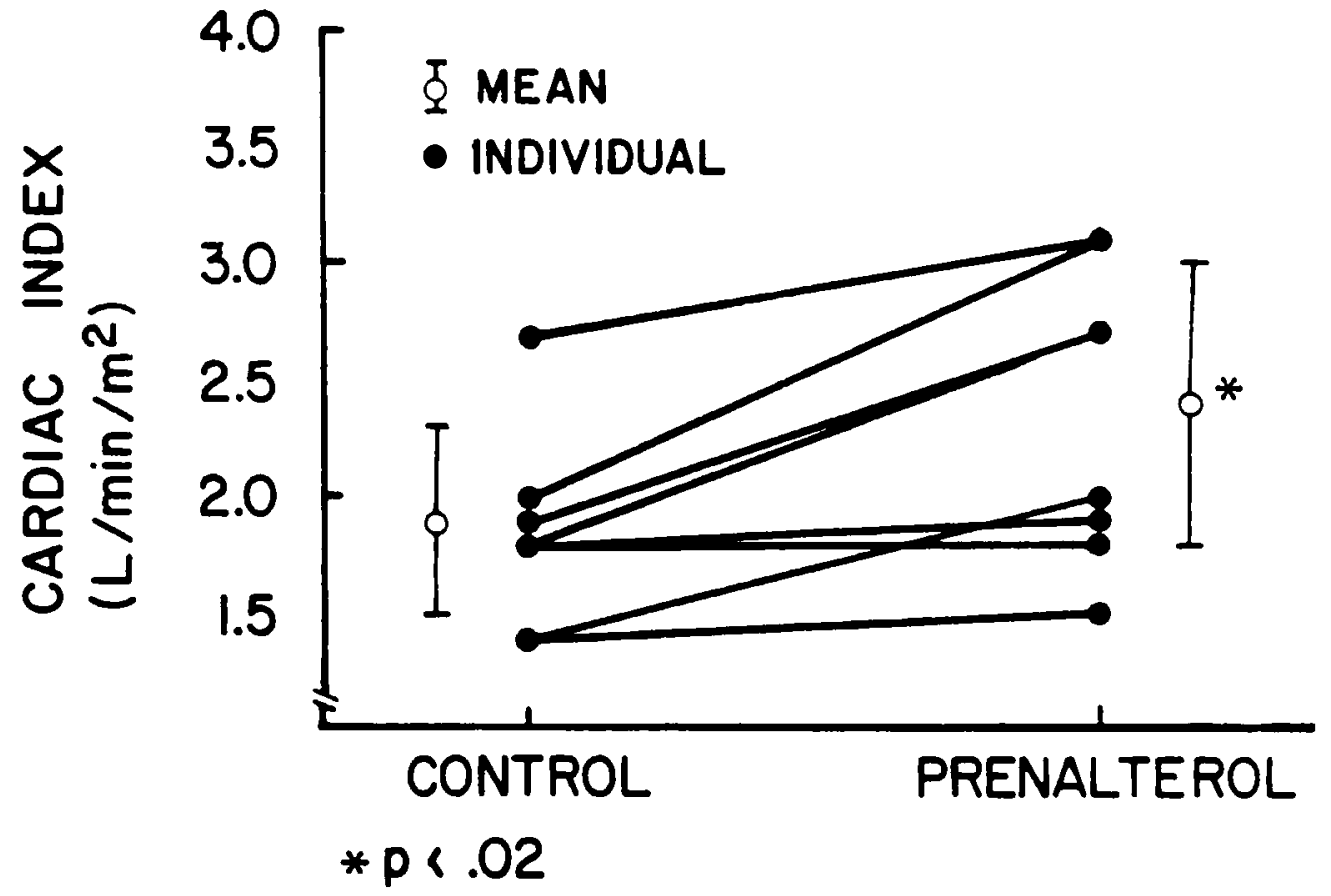

Figure 13. Effect of prenalterol on cardiac index in patients. A significant increase $(p<0.02)$ occurred.

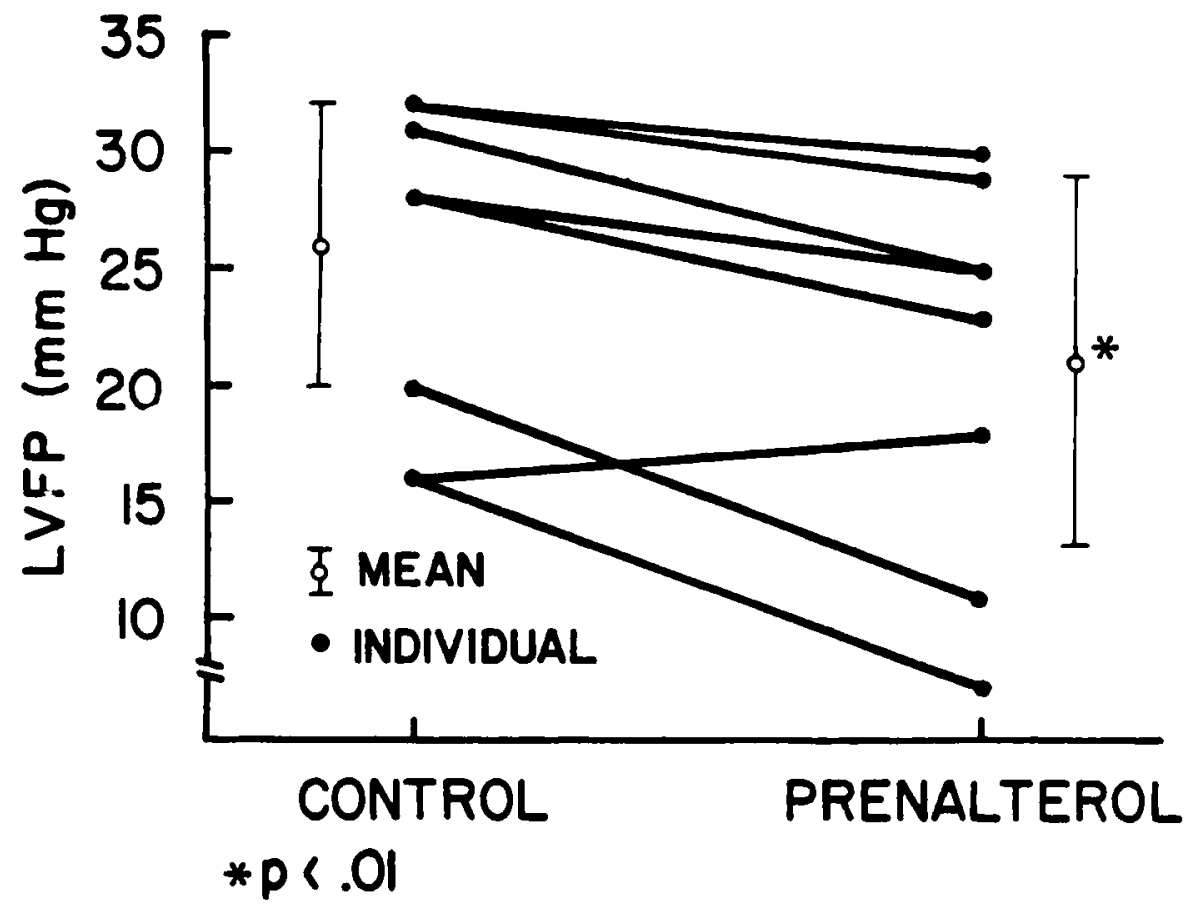

Figure 14. Effect of prenalterol on left ventricular filling pressure (LVFP) in patients. A significant reduction $(p<0.01)$ occurred. 


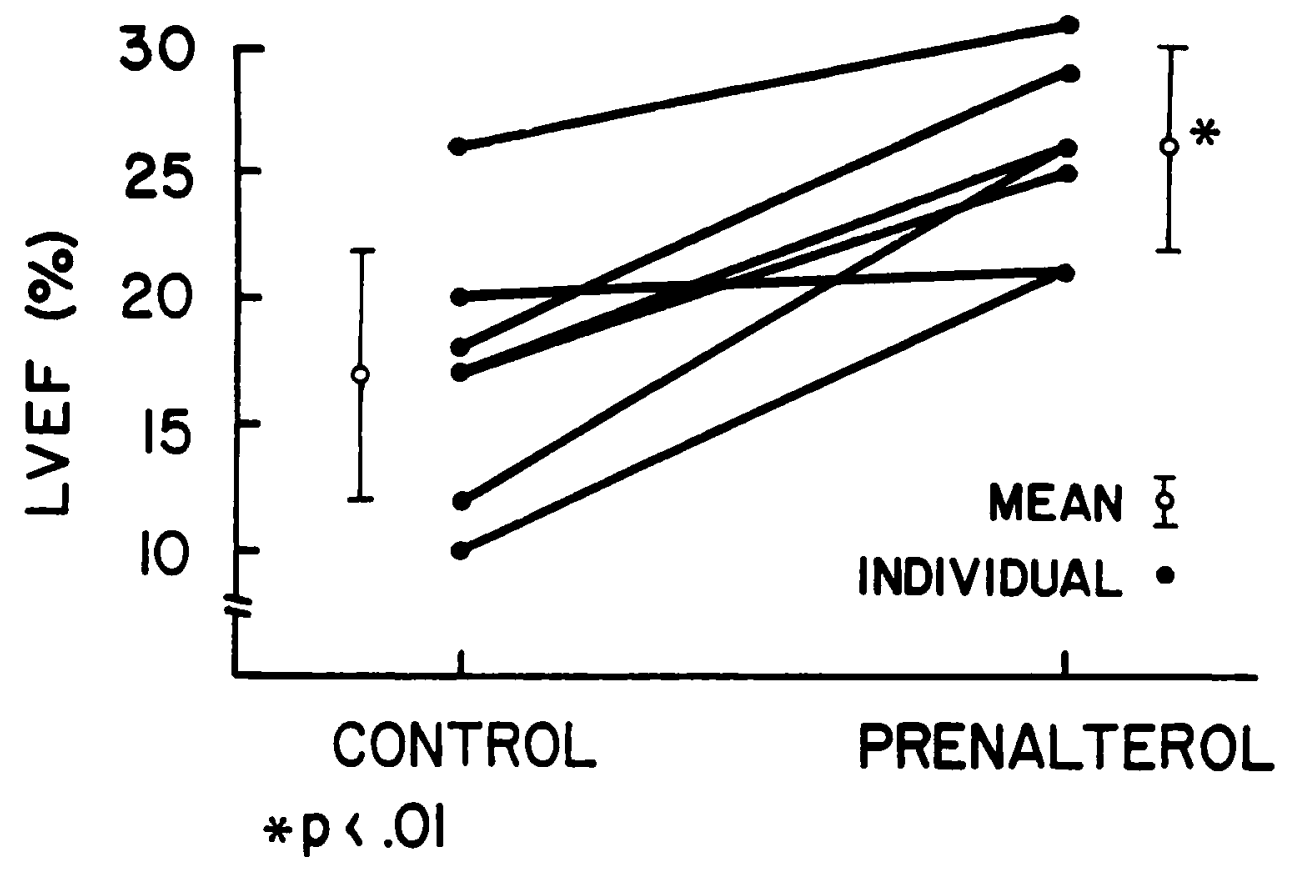

Figure 15. Effect of prenalterol on left ventricular ejection fraction (LVEF) in patients. A significant increase $(p<0.01)$ occurred. In one patient there was no response.

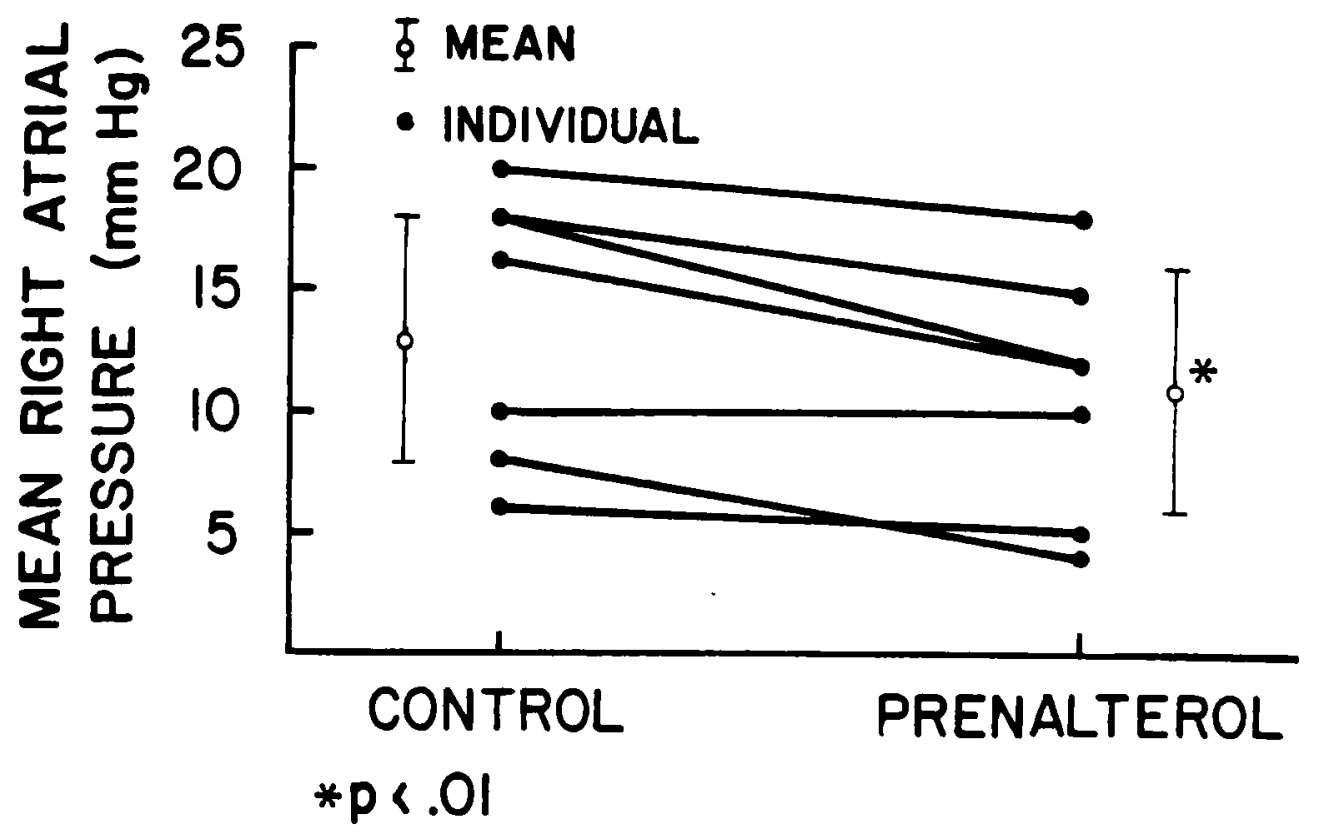

Figure 16. Effect of prenalterol on mean right atrial pressure in patients. A significant reduction $(p<0.01)$ occurred. 


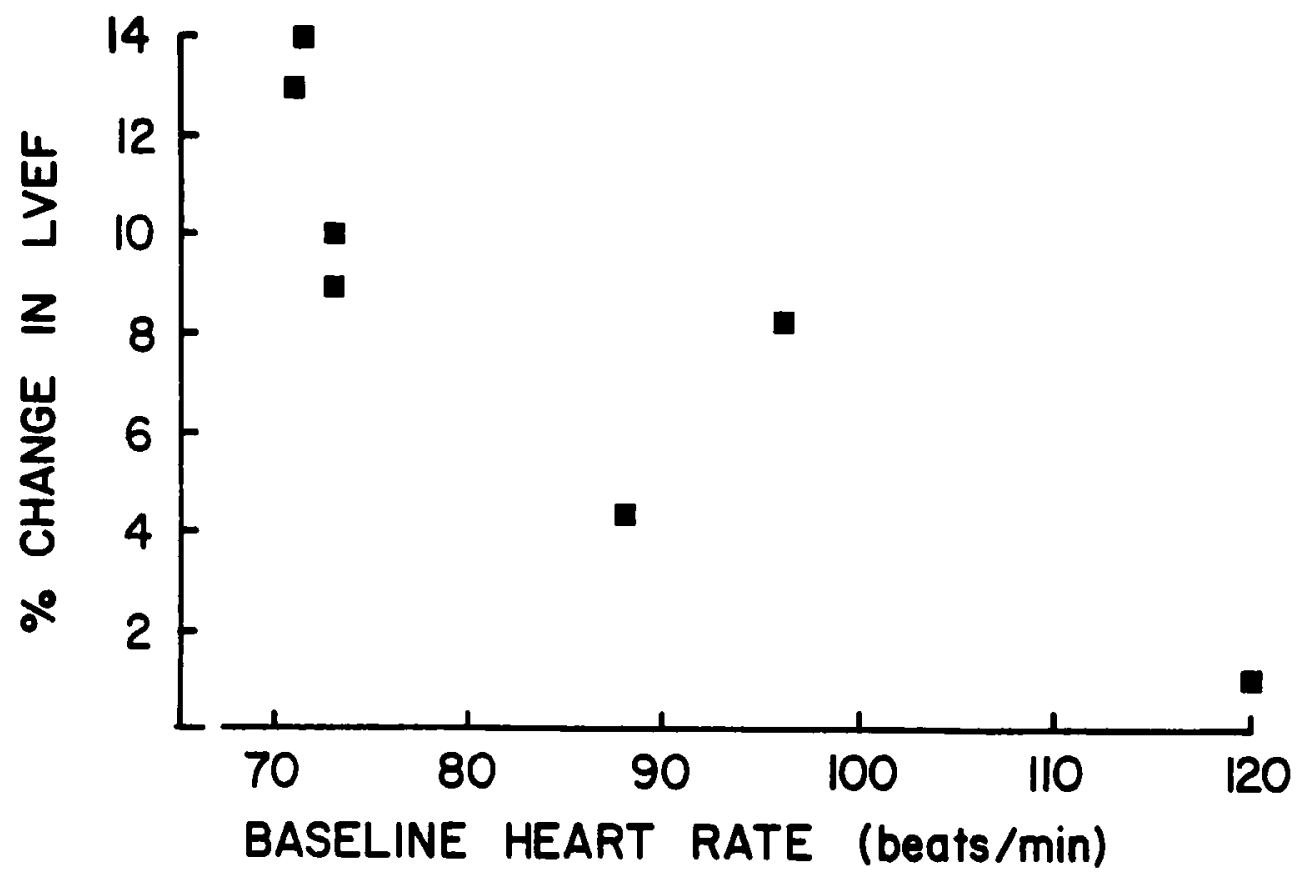

Figure 17. Correlation in patients between increase in left ventricular ejection fraction (LVEF) with prenalterol and baseline heart rate prior to drug administration. A significant inverse correlation was present $(r=-0.89, p<0.01)$.

\section{Prenalterol}

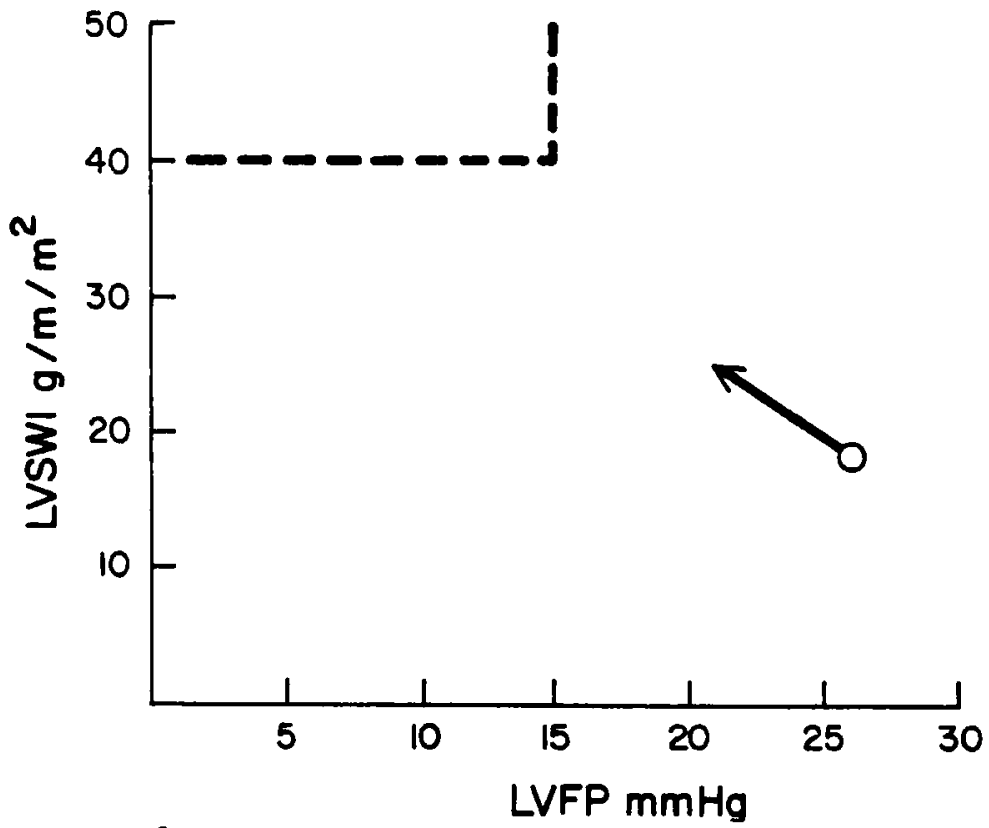

Figure 18. Net effect of prenalterol on left ventricular stroke work index (LVSWI) plotted against left ventricular filling pressure (LVFP) in patients. Values represent mean before (open circle) and after (arrow) prenalterol. Normal values are represented by dotted lines. 
Arrhythmia analysis was obtained from continuous ECG (Holter) monltoring for at least 8 hours prior to prenalterol administration, as well as during and several hours after drug administration.

Statistical analysis was performed by t-test for palred data, comparing control measurements and peak effect. Values are expressed as mean \pm SD.

RESULTS

\section{Experimental acute ischemic heart failure}

An acute ischemic low output state was present after two vessel coronary artery constriction, with significant decreases in cardiac output (from $2.3 \pm 0.2$ to $1.7 \pm 0.1 \mathrm{l} / \mathrm{min}$ ), LV dP/dt $\max$ (from $1654 \pm 58$ to $1395 \pm 60 \mathrm{~mm} \mathrm{Hg} / \mathrm{s}$ ), ischemic zone contractile force (from $96 \pm 7$ to $58 \pm 7 \mathrm{~g}$ ), non-1schem1c zone contract1le force (from $38 \pm 5$ to $34 \pm 5 \mathrm{~g}$ ) and mean arterial pressure (from $95 \pm 4$ to $90 \pm 3 \mathrm{~mm} \mathrm{Hg}$ ) and signiflcant increases in LVEDP (from $7 \pm 1$ to $17 \pm 2 \mathrm{~mm} \mathrm{Hg}$ ) and total peripheral resistance (from $3461 \pm 234$ to $4470 \pm 300 \mathrm{dyn} \cdot \mathrm{s} \cdot \mathrm{cm}^{-5}$ ).

Dose-response curve analysis demonstrates that both intravenous prenalterol and dobutamine cause significant dose-dependent increases in cardiac output (Figure 6), IV dP/dt $\max$ (Figure 7) and non-ischemic zone contractile force (Figure 8) compared to saline controls, as well as a significant dose-dependent decrease in systemic vascular resistance (F1gure 10). However, ischemic zone contractile force did not change signiflcantly after elther inotroplc agent compared to saline controls (Figure 9). Increases in mean arterial pressure were significantly greater during dobutamine infusion (but not prenalterol infusion) than in control animals (Figure 4). Dobutamine tended to cause greater increases in heart rate at higher doses than saline (Figure 3) but this difference did not achieve statistical significance. Prenalterol caused no significant changes in heart rate. The greater increase in heart rate associated with dobutamine, however, largely accounts for the significantly higher cardiac output during high dose 
dobutamine infusion, as stroke volume was not different in the two groups of animals treated with inotropic agents ( $>0.22$, not graphea). Pressure rate product, an index of myocardial oxygen consumption [4], was calculated by multiplying systolic arterial pressure by heart rate, divided by 100. As shown in Figure 5, dobutamine caused significantly greater increases than either saline or prenalterol. LVEDP did not change significantly after either inotropic agent.

Arrhythmia analysis revealed that neither dobutamine nor prenalterol increased the number of 1solated ectopic beats. Both Inotropic agents, however, caused sustained ventricular tachyarrhythmias. One animal suffered ventricular fibrillation during $5 \mu \mathrm{g} / \mathrm{kg} / \mathrm{min}$ prenalterol infusion, and one animal developed ventricular tachycardia during $3 \mu \mathrm{g} / \mathrm{kg} / \mathrm{min}$ dobutamine infusion. Saline treated animals had no ventricular tachyarrhythmias.

The duration of the hemodynamic effect was substantially longer after discontinuation of prenalterol than dobutamine, with hemodynamic half-lives (change in non-ischemic zone contractile force) of 3 hours and $1.7 \mathrm{~min}$ respectively.

\section{Chronic heart fallure in patients}

Baseline hemodynamic measurements prior to drug administration confirmed severe heart fallure in all patients (Table I, Figures 11-16). Left ventricular ejection fraction ranged from 10-26\% with a mean of $17 \pm 5 \%$; cardiac index ranged from 1.4 to $2.71 / \mathrm{m} 1 \mathrm{n} / \mathrm{m}^{2}$ with a mean of $1.7 \pm 0.41 / \mathrm{min} / \mathrm{m}^{2}$; left ventricular stroke work index ranged from $12-28 \mathrm{~g} \mathrm{~m} / \mathrm{m}^{2}$ with a mean of $18 \pm 6 \mathrm{~g} \mathrm{~m} / \mathrm{m}^{2}$; and left ventricular f1lling pressure ranged from $16-32 \mathrm{~mm} \mathrm{Hg}$ (mean $26 \pm 6 \mathrm{~mm} \mathrm{Hg}$ ). Elevated systemic arteriolar resistance (mean $1872 \pm 493 \mathrm{dyn} \cdot \mathrm{s} \cdot \mathrm{cm}^{-5}$ ) and pulmonary arteriolar resistance (mean $338 \pm 129$ dyn.s. $\mathrm{cm}^{-5}$ ) were also present.

Peak hemodynamic effects after prenalterol administration are shown in Figures 11-16 and Table $I$. Significant increases in left ventricular ejection fraction (to $26 \pm 4 \%$ ), cardiac index (to $2.4 \pm 0.6$ $1 / \mathrm{min} / \mathrm{m}^{2}$ ) and left ventricular stroke work index (to $25 \mathrm{~g} \cdot \mathrm{m} / \mathrm{m}^{2}$ ) 


\begin{tabular}{|c|c|c|c|c|c|c|c|c|c|}
\hline Pt \# & Age & Sex & Diagnosis & \multicolumn{2}{|c|}{$\begin{array}{r}\text { Heart Rate } \\
\text { (beats/min) }\end{array}$} & \multicolumn{2}{|c|}{$\begin{array}{l}\text { Systolic Arterial } \\
\text { Puessure (mmig) }\end{array}$} & \multicolumn{2}{|c|}{$\begin{array}{l}\text { Mean Arterial } \\
\text { Pressure (mmHg) }\end{array}$} \\
\hline 1 & 63 & $M$ & Ischemic & 75 & 80 & 116 & 120 & 90 & 92 \\
\hline 2 & 53 & $F$ & Alcohol ic & 74 & 83 & 110 & 130 & 94 & 98 \\
\hline 3 & 64 & $F$ & Ischemic & 39 & 106 & 135 & 140 & 84 & 91 \\
\hline 4 & 56 & $F$ & Idiopathic & 120 & 122 & 118 & 130 & 87 & 98 \\
\hline 5* & 60 & $F$ & Ischemic & 110 & - & 102 & - & 74 & - \\
\hline 6 & 48 & M & Idiopathic & 71 & 90 & 128 & 135 & 92 & 93 \\
\hline 7 & 64 & M & Ischemic & 96 & 102 & 135 & 140 & 97 & 100 \\
\hline 8 & 55 & M & Ischemic & 75 & 75 & 108 & 120 & 88 & 94 \\
\hline 9 & 70 & $M$ & Ischemic & 72 & 68 & 104 & 107 & 74 & 77 \\
\hline
\end{tabular}

Mean \pm SD $59 \pm 7$ pro Baseline

$87 \pm 18-91 \pm 78$

0.05

0.004

0.007

*Pt \#5 experienced ventricular tachycardia after $1 \mathrm{mg}$ infusion and was excluded from further analysis.

\begin{tabular}{|c|c|c|c|c|c|c|c|c|}
\hline \multirow[b]{2}{*}{ Pt: } & \multicolumn{2}{|c|}{$\begin{array}{l}\text { Diastolic Arterial } \\
\text { Pressure (mm }\end{array}$} & \multicolumn{2}{|c|}{$\begin{array}{c}\text { LVEF } \\
(\%)\end{array}$} & \multicolumn{2}{|c|}{$\frac{\text { LVSWI }}{\left(\mathrm{g} m \cdot \mathrm{m} / \mathrm{m}^{2}\right)}$} & \multicolumn{2}{|c|}{$\begin{array}{c}\text { Cardlac Index } \\
\left(\mathrm{L} / \mathrm{min} / \mathrm{m}^{2}\right)\end{array}$} \\
\hline & Baseline & Maximum & Baseline & Maximum & Baseline & Maximum & Baseline & Maximum \\
\hline 1 & 78 & 78 & 17 & 26 & 21 & 28 & 1.9 & 2.7 \\
\hline 2 & 86 & 88 & $\star \star$ & $\star \star$ & 22 & 21 & 1.8 & 1.8 \\
\hline 3 & 62 & 67 & 26 & 31 & 28 & 30 & 2.7 & 3.1 \\
\hline 4 & 71 & 85 & 20 & 21 & 12 & 17 & 1.8 & 1.9 \\
\hline 5 & 62 & - & 12 & - & 12 & - & 2.0 & - \\
\hline 6 & 78 & 75 & 18 & 29 & 27 & 40 & 2.0 & 3.2 \\
\hline 7 & 78 & 82 & 17 & 25 & 16 & 22 & 1.8 & 2.7 \\
\hline 8 & 75 & 76 & 10 & 21 & 17 & 28 & 1.4 & 2.0 \\
\hline 9 & 60 & 65 & 12 & 26 & 12 & 15 & 1.4 & 15. \\
\hline $\begin{array}{l}\text { Mean } \pm \text { SD } \\
\text { Pvs Baseline }\end{array}$ & $72 \pm 9$ & $\begin{array}{c}77 \pm 8 \\
0.09 \\
\end{array}$ & $17 \pm 5$ & $\begin{array}{l}26 \pm 4 \\
0.002\end{array}$ & $8 \pm 6$ & $\begin{array}{l}25 \pm \cdot 8 \\
0.008\end{array}$ & $9 \pm 0.4$ & $\frac{2.4 \pm 0.5}{0.015}$ \\
\hline
\end{tabular}

m" Technically unsatisfactory radionuclide cardiac blood pool scan

LVEF = Left Ventricular Ejection Fraction

LVSWI = Left Vent: icular Stroke Work Index

\begin{tabular}{|c|c|c|c|c|c|c|c|c|}
\hline \multirow[b]{2}{*}{ Pt } & \multicolumn{2}{|c|}{$\begin{array}{c}\text { LVFP } \\
(\mathrm{mmHg})\end{array}$} & \multicolumn{2}{|c|}{$\begin{array}{c}\overline{P A P} \\
(\mathrm{mmHg})\end{array}$} & \multicolumn{2}{|c|}{$\begin{array}{l}\text { Systematic Arteri- } \\
\text { olar Resistance } \\
\left.\text { (dynes.sec } \cdot \mathrm{cm}^{-5}\right)\end{array}$} & \multicolumn{2}{|c|}{$\begin{array}{c}\text { Mean Right } \\
\text { Atrial Pressure } \\
\text { (mmg) }\end{array}$} \\
\hline & Basel ine & Minimum & Baseline & Minimum & Baseline & $M+n^{i} m^{\prime} 1 m$ & Baseline & Minimum \\
\hline 1 & 31 & 25 & 54 & 41 & - & - & 10 & NA \\
\hline 2 & 28 & 25 & 42 & 40 & 2229 & 2289 & 16 & 12 \\
\hline 3 & 16 & 18 & 34 & 36 & 1460 & 1280 & 10 & 10 \\
\hline 4 & 28 & 23 & 34 & 30 & 1786 & 2075 & 18 & 15 \\
\hline 5 & 26 & - & 34 & - & 1449 & - & 12 & - \\
\hline 6 & 20 & 11 & 31 & 22 & 1446 & 903 & 6 & 5 \\
\hline 7 & 32 & 30 & 51 & 49 & 2133 & 1413 & 18 & 12 \\
\hline 8 & 16 & 7 & 26 & 17 & 2802 & 2071 & 8 & 4 \\
\hline 9 & 32 & 29 & 45 & 40 & 1780 & 1692 & 20 & 18 \\
\hline $\begin{array}{l}\text { Mean } \pm \text { SD } \\
\frac{\text { P }}{\text { pis Baseline }}\end{array}$ & $26 \pm 6$ & $\begin{array}{l}21 \pm 8 \\
0.01\end{array}$ & $39 \pm 9$ & $\begin{array}{c}34 \pm 11 \\
0.02\end{array}$ & $1872 \pm 493$ & $\frac{1674 \pm 502}{0.11}$ & $13 \pm 5$ & $\begin{array}{l}71 \pm 5 \\
0.01\end{array}$ \\
\hline
\end{tabular}


occurred with signiflcant decreases in left ventricular filling pressure (to $21 \pm 8 \mathrm{~mm} \mathrm{Hg}$ ), pulmonary arteriolar resistance (to $215 \pm 85 \mathrm{dyn} \cdot \mathrm{s} \cdot \mathrm{cm}^{-5}$ ) and mean right atrial pressure (to $11 \pm 5 \mathrm{~mm} \mathrm{Hg}$ ). Systemic arteriolar resistance declined (to $1674 \pm 502 \mathrm{dyn} \cdot \mathrm{s} \cdot \mathrm{cm}^{-5}$ ) without achieving significance $(p>0.11)$. Heart rate increased significantly (from $87 \pm 18$ to $91 \pm 18$ beats/min) as did mean arterial pressure (from $87 \pm 8$ to $92 \pm 7 \mathrm{~mm} \mathrm{Hg}$ ).

Variable hemodynamic responses were noted (Table I, Figures 11-16) and no slgniflcant differences among peak effects at different doses were present. Correlation between response (as measured by increase in LVEF) with several baseline parameters revealed that basal heart rate was inversely correlated with increase in ejection fraction following prenalterol ( $r=-0.89, p<0.01$, Figure 17).

Holter monitor analysis demonstrated that two patients developed increased numbers of ectopic ventricular complexes during prenalterol administration and two other patients developed unsustained ventricular tachycardia. Both of the latter patients had ischemic cardiomyopathy treated with digoxin at the time of study without antiarrhythmic therapy.

No subjective adverse effects were noted and no electrocardlographic evidence of worsening ischemia was seen.

\section{DISCUSSION}

The present studies demonstrate that intravenous prenalterol causes signiflcant hemodynamic improvement in both acute and chronic low output states, and that its effects are comparable to those of dobutamine in a canine model of acute 1schemic heart failure. Previous investigations of prenalterol indicate that its inotropic action is due to myocardial $\beta_{1}$-receptor stimulation $[1,5]$, although the drug binds non-selectively to other $\beta-r e c e p t o r s ~[5,6]$ and 1 t possesses $\beta_{2}$-adrenergic antagonistic activity $[6,7]$. Isolated tissue preparation studies have demonstrated that prenalterol has less intrinsic $\beta$-agonist effect than 1soproterenol $[5,6]$. Thus, prenalterol could be classified as a partial B-agonist with relatively selective myocardial $\beta_{1}$-stimulating 
properties and 1nherent $B$-adrenergic antagonistic effect in some other tissues. It is of interest that prenalterol does not elevate myocardial adenylate cyclase levels [5], as would be anticlpated with catecholamines. This fact, in addition to its non-catecnolamine structure and 1ts prolonged hemodynamic effect ralses the possiblilty that prenalterol's mechanism of action and route of metabolism may, in part, differ from those of catecholamine inotropic agents.

Results from this study are in agreement with previous investigations of prenalterol in normal experimental animals [1] and normal volunteers $[2,3]$, as well as patients with ventricular dysfunction [8, 9]. Hemodynamic improvement appears to result from both inotropic stimulation and a reduction in left ventricular outflow resistance (afterload reduction). Although difficulties exist in distinguishing afterload reduction from inotropic stimulation in the intact subject, a predominant inotropic effect of prenalterol is suggested by [1] its relatively selective $\beta_{1}$-stimulating effect with $\beta_{2}$-blocking activity consistent with myocardial $\left(\beta_{1}\right)$ stimulation but little or no peripheral arteriolar $\left({ }_{2}\right)$ stimulation and [2] an increase in mean systemic arterial pressure despite a decrease in systemic arteriolar resistance (Table I) in contrast to the decline in blood pressure or minimal blood pressure effect associated with vasodilators [10]. It is possible that the decrease in peripheral vascular resistance caused by prenalterol is in part reflexively mediated by baroreceptor stimulation due to blood pressure elevation. The net hemodynamic effect of prenalterol is a shift in the ventricular function curve upward and to the left (Figure 18), as noted with other inotropic agents.

In addition to its positive inotropic and afterload reducing properties, prenalterol appears to possess a preload reducing (venodilating) effect, as evidenced by a reduction in left ventricular filling pressure (Figure 14) and a reduction in mean right atrial pressure (Figure 16) in patients with heart fallure. Similar results have been reported following dobutamine administration $[10,11]$. The fallure of dobutamine and prenalterol to lower left ventricular end-diastolle pressure compared to saline 
controls in the present animal investigation may be related to differences between the acute ischemic canine model of heart fallure and the more chronic, stable left ventricular failure present in the patients studied.

Also of interest is prenalterol's ab111ty to reduce elevated pulmonary vascular resistance in heart fallure (Table I), similar to the effect of dobutamine as reported by Mikulic et al. [10]. This may be an additional contributing factor to the patients' hemodynamic improvement.

In the canine model of acute 1schemic heart fallure prenalterol and dobutamine caused similar increases in LV dP/dt ${ }_{\max }$ and non-1schemic zone contractile force and simflar reductions in systemic vascular resistance. Differences existed, however, in prenalterol's markedly longer duration of action and the greater increases in cardiac output, mean arterial pressure and pressure rate product associated with dobutamine.

Prenalterol's longer duration of action represents a potential advantage over dobutamine if sustained inotropic effect after discontinuation of infusion is desirable, but it could be disadvantageous in the presence of an adverse reaction. The greater cardiac output assoclated with high doses of dobutamine may be an advantage relative to prenalterol, but it is primarily due to greater increases in heart rate and is assoclated with

significantly greater increases in pressure rate product indicative of higher myocardial oxygen demand, a potential1y deleterious effect in acute ischemia. A possible explanation for this difference in pressure rate product changes is the partial $\beta$-agonistic property of prenalterol, which may limit heart rate and blood pressure increases at higher doses.

The extent of ischemic injury following prenalterol and dobutamine was not assessed in this animal study, but previous investigations with dobutamine indicate that it is not associated with increased infarct size in either experimental [12] or clinical [13] myocardial infarction. Because prenalterol causes less blood pressure and heart rate increase than dobutamine, it is even less 
likely to be assoclated with increased 1schemic damage.

The administration of both inotropic agents was associated with ventricular arrhythmias in the acute ischemic canine model and two prenalterol treated patients with ischemic cardiomyopathy developed ventricular tachycardia. While arrhythmias due to catheterization or 1schemia per se cannot be excluded, their occurrence during drug administration and the absence of sustained rhythm disturbances in saline control animals suggest a cause and effect relationship between dobutamine and prenalterol administration and ventricular arrhythmias. Th1s finding is consistent with prior experience with adrenergic inotropic agents [14]. Both prenalterol treated patients with ventricular tachycardia were chronically digitalized, ralsing the possibility that the combination of digoxin and adrenergic stimulation in the presence of severe 1schemic heart disease may induce arrhythmias.

The considerable variation in response to prenalterol and the lack of significant differences among peak hemodynamic responses to varying doses in the patient study may be related to the drug's intrinsic $\beta$-adrenergic blocking effect, which could inhibit further response at higher doses. This may also account for the lower plateau compared to dobutamine in dose-response curves noted in the animal study (Figures 5-7). The inverse correlation between baseline heart rate and increase in left ventricular ejection fraction with prenalterol (F1gure 17) may also explain in part the variability of patient response, and suggests that increased resting sympathetic tone (as manifested by tachycardia) may limit the response to further stimulation by adrenergic inotropic agents.

In conclusion, intravenous prenalterol results in hemodynamic Improvement in patients with severe chronic heart fallure and in a canine model of an acute ischemic low output state. The drug's hemodynamic effects are equivalent to those of dobutamine in the canine model except for prenalterol's longer duration of action and greater increases in heart rate and blood pressure at high dose dobutamine, resulting in higher pressure rate product and cardlac output. The primary mechanisms of prenalterol $\mathrm{s}$ beneficial hemodynamic effect appear to be an increase in contractile force, 283 
greater in non-ischemic than in severely ischemic tissue, and a reduction of systemic vascular resistance. Reductions in pulmonary vascular resistance and systemic venous pressure may also contribute to 1ts beneficlal effect. However, ventricular arrhythmias may be associated with prenalterol, as with other inotropic stimulants, and the drug should be administered with careful electrocardiographic monitoring.

\section{ACKNOWLEDGEMENTS}

The authors wish to acknowledge the contributions of the following Individuals: Steven Hewlett, Kathleen Worthington, Jean Clare, Edward Driscol1, John K. Gibson, Ph.D., M.A. Schork, Ph.D., Theresa Johnson, R.N., and the nursing staff of the Cardiac Intensive Care Unit, University of Michigan Medical Center. This work was supported in part by the Michigan Heart Association (Dr. KIrlin, Research Fellow) and the National Institutes of Health (NHLBI - HL - 19782 - 03). Astra Pharmaceutical Products, Inc., also provided grant support and generously supplied prenalterol.

\section{REFERENCES}

1. Carlsson, E., Dahlöf, C.-G., Hedberg, A., Persson, H. \& Tångstrand, B.: Differentiation of cardiac chronotropic and inotropic effects of $\beta$-adrenoceptor agonists. Naunyn Schmledebergs Arch Pharmacol 300:101-105, 1977.

2. Rönn, O., Graffner, C., Johnsson, G., Jordö, L., Lundborg, P. \& Wikstrand, J.: Haemodynamic effects and pharmacokinetics of a new selective beta ${ }_{1}$-adrenoceptor agonist, prenalterol, and its Interaction with metoprolol in man. Fur $J$ Clin Pharmacol $15: 9-13,1979$.

3. Knaus, M., Pfister, B., Dubach, U.C. \& Imhof, P.: Human pharmacology studies with a new, orally active stimulant of cardiac adrenergic beta-receptors. Am Heart J 95:602-610, 1978.

4. Rushmer, R.F.: Cardiovascular dynamics, p. , 3584 ed. W.B. 
Saunders Company. Philadelphia 1976.

5. Hedberg, A., Mattsson, H. \& Carlsson, E.: Prenalterol, a non-selective $B$-adrenoceptor 11 gand with absolute $\beta_{1}$-selective partial agonist activity. J Pharm Pharmacol 32:660-661, 1980 .

6. Kenakin, T.P. \& Beek, D.: Is prenalterol (H 133/80) really a selective $B_{1}$-adrenoceptor agonist? Tissue selectivity resulting from differences in stimulus-response relationships. $J$ Pharmacol Exp Ther 213:406-413, 1980.

7. Johansson, U. \& Waldeck, B.: On the stereospeciflc1ty of the ${ }_{2}$-adrenoceptor blocking properties of prenalterol. J Pharm Pharmacol 32:659-660, 1980 .

8. Hutton, I., Murray, R.G., Boyes, R., Rae, A. \& Hillis, W.S.: Haemodynamic effects of prenalterol in patients with coronary heart disease. Br Heart J 43:134-137, 1980.

9. Ariniego, R., Waagstein, F., Mombay, B. \& Hjalmarson, A.:

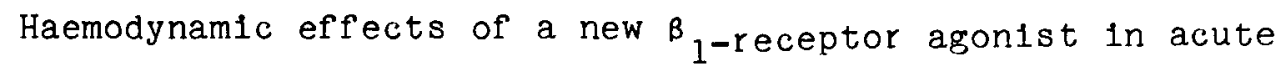
myocardial infarction. A useful antidote to unwanted cardiac effects of $\beta$-block1ng agents. Br Heart J 42:139-146, 1979.

10. Mikulic, E., Cohn, J.N. \& Franciosa, J.A.: Comparative hemodynamic effects of inotropic and vasodilator drugs in severe heart fallure. Circulation 56:528-533, 1977 .

11. Loeb, H.S., Bredak1s, J. \& Gunnar, R.M.: Superiority of dobutamine over dopamine for augmentation of cardiac output in patients with chronic low output cardiac fallure. Circulation 55:375-381, 1977 .

12. Tuttle, D.R., Pollock, G.D., Todd, G., MacDonald, D., Trust, R.

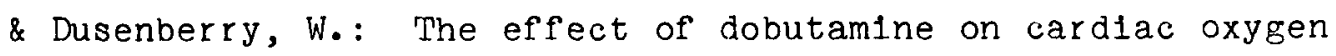
balance, regional blood-flow, and infarction severity after coronary artery narrowing in dogs. Circ Res 41:357-364, 1977 .

13. Gillespie, T.A., Ambos, H.D., Sobel, B.E, \& Roberts, R.: 
Effects of dobutamine in patients with acute myocardial infarction. Am J Cardiol 39:588-594, 1977.

14. Sonnenblick, E.H., Frishman, W.H. \& LeJemtel, T.H.:

Dobutamine: a new synthetic cardioactive sympathetic amine. N Engl J Med 300:17-22, 1979. 